\title{
Seedling Interference and Niche Differentiation Between Crested Wheatgrass and Contrasting Native Great Basin Species
}

\author{
Kevin L. Gunnell, ${ }^{1}$ Thomas A. Monaco, ${ }^{2}$ Christopher A. Call, ${ }^{3}$ and Corey V. Ransom ${ }^{4}$ \\ Authors are ${ }^{1}$ Former Graduate Research Assistant, and ${ }^{3}$ Associate Professor, Department of Wildland Resources, Utah State University, Logan, UT \\ 84322, USA; ${ }^{2}$ Ecologist, US Department of Agriculture-Agricultural Research Service Forage and Range Research Laboratories, Logan, UT 84322, USA; \\ and ${ }^{4}$ Assistant Professor, Plants, Soils, and Climate Department, Utah State University, Logan, UT 84322, USA.
}

\begin{abstract}
Interference from crested wheatgrass (Agropyron cristatum [L.] Gaertn.) seedlings is considered a major obstacle to native species establishment in rangeland ecosystems; however, estimates of interference at variable seedling densities have not been defined fully. We conducted greenhouse experiments using an addition-series design to characterize interference between crested wheatgrass and four key native species. Crested wheatgrass strongly interfered with the aboveground growth of Wyoming big sagebrush (Artemisia tridentata Nutt. subsp. wyomingensis Beetle \& Young), rubber rabbitbrush (Ericameria nauseosa [Pall. ex Pursh] G. L. Nesom \& Baird subsp. consimilis [Greene] G. L. Nesom \& Baird), and to a lesser extent with bluebunch wheatgrass (Pseudoroegneria spicata [Pursh] A. Löve). Alternatively, bottlebrush squirreltail (Elymus elymoides [Raf.] Swezey subsp. californicus [J. G. Sm.] Barkworth) and crested wheatgrass had similar effects on each other's growth, and interference ratios were near 1.0. Results indicate that the native grasses more readily establish in synchrony with crested wheatgrass than these native shrubs, but that once established, the native shrubs are more likely to coexist and persist with crested wheatgrass because of high niche differentiation (e.g., not limited by the same resource). Results also suggest that developing strategies to minimize interference from crested wheatgrass seedlings emerging from seed banks will enhance the establishment of native species seeded into crested wheatgrass-dominated communities.
\end{abstract}

\section{Resumen}

La interferencia por parte de plántulas de agropiro crestado (Agropyron cristatum [L.] Gaertn.) se considera un obstáculo mayor para el establecimiento de especies nativas en ecosistemas de pastizal natural; sin embargo, las estimaciones de interferencia con densidades variables de plántulas no han sido definidas con precisión. Se condujo un experimento de invernáculo utilizando un diseño de series de adición para caracterizar la interferencia entre agropiro crestado y cuatro especies nativas clave. Se observó una interferencia marcada del agropiro crestado sobre el crecimiento aéreo de Artemisia tridentata Nutt. subsp. wyomingensis Beetle \& Young, Ericameria nauseosa (Pall. ex Pursh) G. L. Nesom \& Baird subsp. consimilis (Greene) G. L. Nesom \& Baird, y en menor medida con Pseudoroegneria spicata (Pursh) A. Löve. Por otra parte, Elymus elymoides (Raf.) Swezey subsp. californicus (J. G. Sm.) Barkworth y el agropiro crestado tuvieron efectos recíprocos similares sobre el crecimiento de cada uno, y la proporción de interferencia fue cercana a 1.0. Los resultados indican que los pastos nativos se establecen con mayor facilidad que los arbustos nativos en sincronía con el agropiro crestado, pero que una vez establecidos, hay mayor probabilidad de que los arbustos nativos coexistan y persistan con el agropiro crestado debido a la diferenciación de nichos (ej., no están limitados por el mismo recurso). Los resultados también sugieren que el desarrollo de estrategias para minimizar la interferencia por parte de plántulas de agropiro crestado provenientes de bancos de semillas mejorará el establecimiento de especies nativas inter-sembradas en comunidades dominadas por el agropiro crestado.

Key Words: addition series, assisted succession, competitive ability, native species, Wyoming big sagebrush communities

\section{INTRODUCTION}

Native vegetation in numerous North American ecosystems has been converted to managed grazing systems by planting exotic perennial grasses to remediate the impacts of pervasive disturbances and improve forage potential. The ecological impact of these conversions is beginning to be understood for buffelgrass (Pennisetum ciliare [L.] Link) in the Sonoran Desert

Mention of a proprietary product does not constitute a guarantee or warranty of the product by US Department of Agriculture or the authors and does not imply its approval to the exclusion of other products that also may be suitable.

Correspondence: T. A. Monaco, USDA-ARS, Utah State University, Logan, UT 84322-6300, USA. Email: tom.monaco@ars.usda.gov

Manuscript received 27 August 2009; manuscript accepted 30 January 2010.
(Morales-Romero and Molina-Freaner 2008), Lehmann lovegrass (Eragrostis lehmanniana Nees) in the Chihuahuan desert (Bock et al. 2007), Old World bluestems (Bothriochloa spp.) in the southern Great Plains (Schmidt et al. 2008), and crested wheatgrass in the northern Great Plains and the Great Basin (Henderson and Naeth 2005). Each of these examples shares a common thread in that the exotic grasses are more grazing tolerant and competitive than native species. Consequently, understanding the outcome of interactions between exotic grasses and the displaced native species is an important consideration for ecosystem management.

Big sagebrush-dominated (Artemisia tridentata Nutt.) ecosystems that have been seeded with crested wheatgrass (Agropyron cristatum [L.] Gaertn.) can develop low plant diversity when disturbance regimes and soil attributes are 
unfavorable for recruitment and survival of native species (Mueggler and Blaisdell 1958; Evans and Young 1978; Sharp et al. 1992). Low-diversity conditions also can be perpetuated by crested wheatgrass interference because it has more rapid nutrient acquisition and faster root growth than native species under cold temperatures when soil resources are abundant (Eissenstat and Caldwell 1987; Aguirre and Johnson 1991). Crested wheatgrass also has high seed production and dominates seed banks (Marlette and Anderson 1986; Pyke 1990; Sharp et al. 1992), and its interference on establishment and growth of coexisting species is compounded as seedling density increases (Francis and Pyke 1996). Although crested wheatgrass stands resist invasion by annual grasses such as downy brome (Bromus tectorum L.), they also can impede efforts to increase diversity by seeding with native species (Cox and Anderson 2004; Pellant and Lysne 2005). However, empirical estimates of how crested wheatgrass seedling densities affect native species growth and establishment have not been defined.

The outcome of interaction between seedlings of crested wheatgrass and native species also largely can depend on functional plant traits of the native species (Pyke and Archer 1991; Chambers and MacMahon 1994). For example, native species dominance during different community phases is attributed to variation in seed dispersal, fire tolerance, resource acquisition, growth rate, and seed production (Biodini et al. 1985; Tueller and Platou 1991). Species that dominate in earlysuccessional community phases, or following disturbances, have traits that enable rapid colonization and vegetative regeneration, whereas dominance in late-successional phases is attributed to tolerance of low resource availability, slow growth, resource conservation, and longevity (Horn 1974; Kleijn 2003; Pywell et al. 2003). This variability suggests the possibility that native species differ markedly in their capacity to interact with crested wheatgrass.

Addition-series designs that systematically vary densities and proportions of different species are an attractive method to interpret relative competitive ability and quantify interference and niche differentiation between species (Spitters 1983; Radosevich 1987; Sheley and Larson 1994). These simple experimental designs enable the modeling of yield-density responses of two-species systems by calculating regression coefficients for intra- and interspecific interference, assuming that both species have equal resource-utilization efficiency (Spitters 1983). When species differentially use resources in time or space, niche differentiation likely is occurring (Jackson and Caldwell 1989; James et al. 2008). Understanding niche relationships is important because they help to predict whether interference between species will result in competitive displacement or species coexistence (Chesson 2000).

We used the addition-series design and the method of Spitters (1983) to evaluate interference and niche differentiation between crested wheatgrass and representative native-grass and shrub species that tend to dominate during early- and latesuccessional community phases. Under controlled greenhouse conditions, four native species were sown separately with crested wheatgrass in mixed-density matrices to evaluate interference relationships. Although this approach focuses on interference during the earliest stages of plant development, and does not represent the entire interference relationship during establishment, it does provide new insights during a critical period that is difficult to evaluate under field conditions. We hypothesized that crested wheatgrass interference would not be equivalent for native species that vary in functional plant traits and growth form. If confirmed, certain native species could be more suitable to colonize rangelands following a reduction in crested wheatgrass dominance and/or to coexist when simultaneously seeded with crested wheatgrass.

\section{MATERIALS AND METHODS}

Seeds of two native shrubs and two native grasses were sown with crested wheatgrass using an addition-series design in replicated greenhouse experiments to evaluate seedling growthinterference models (Radosevich 1987; Gibson et al. 1999). Native species included a grass and a shrub known to dominate at early-successional phases in big sagebrush communities: bottlebrush squirreltail (Elymus elymoides [Raf.] Swezey subsp. californicus; T-1735; collected about $2 \mathrm{~km}$ east of Highway 46 on Turkey Lake Road, Gooding County, Idaho) and rubber rabbitbrush (Ericameria nauseosa [Pall. ex Pursh] G. L. Nesom \& Baird subsp. consimilis [Greene] G. L. Nesom \& Baird); and a grass and a shrub considered late-successional because of characteristic responses to various disturbances: bluebunch wheatgrass (Pseudoroegneria spicata [Pursh] A. Löve; T-1753; collected about $1.5 \mathrm{~km}$ up Howell Canyon Road from Highway 77, Cassia County, Idaho) and Wyoming big sagebrush (Artemisia tridentata Nutt. subsp. wyomingensis Beetle \& Young; Wright and Klemmedson 1965; Young and Miller 1985; Meyer et al. 1989; Redente et al. 1992). Seed was purchased from a commercial seed company (rabbitbrush), or hand collected between 2005 and 2007 from numerous native populations in Utah (big sagebrush), or from single population experimental plots in Utah and Idaho (crested wheatgrass, squirreltail, and bluebunch wheatgrass). The crested wheatgrass cultivar CD-II (Agropyron cristatum [L.] Gaertner $\times$ A. desertorum [Fisch. ex Link] Schult.) was used for experiments. Germination percentages were determined at $20^{\circ} \mathrm{C}$ for $14 \mathrm{~d}$ on blotter paper for all species in April 2008, and these data were used to calculate the seeding densities used in our experiments.

Plastic pots $(11 \mathrm{~cm}$ diameter $\times 23.5 \mathrm{~cm}$ height $)$ were filled with $2.1 \mathrm{~kg}$ of a 3:1 (volume:volume) mix of sandy soil (Preston fine sand [mixed, mesic, Typic Xeropsamments] collected in Cache County, Utah) and peat moss. Seeds were sown on the surface and covered with approximately $2-5 \mathrm{~mm}$ of soil. The native species were sown separately with crested wheatgrass in mixed-density matrices (Radosevich 1987) at the following 16 target densities $\left(\right.$ seeds $\left.\cdot \mathrm{m}^{-2}\right): 100: 100 ; 100: 500 ; 100: 1000$; 100:1 500; 500:100; 500:500; 500:1000; 500:1500; $1000: 100 ; 1000: 500 ; 1000: 1000 ; 1000: 1500 ; 1500: 100$; 1500:500; $1500: 1000 ; 1500: 1500$. Density matrices were arranged in a randomized complete-block design with three blocks (replications) in two trials. Seed densities were chosen such that the midpoint range of densities (500-1000 seed $\cdot \mathrm{m}^{-2}$ ) were similar to the number of seeds applied when drill-seeding crested wheatgrass-dominated plant communities (Fansler 2007; Hulet et al. 2008). Trial 1 was conducted from 6 May through 21 June 2008, and Trial 2 was conducted from 16 May through 1 July 2008. Forty-five d after sowing, seedlings 
were counted, harvested at the soil surface, separated by species, and dried at $60^{\circ} \mathrm{C}$ for $48 \mathrm{~h}$ to determine aboveground dry biomass. Trials were conducted in a greenhouse at the US Department of Agriculture-Agricultural Research Service Forage and Range Research Laboratory in Logan, Utah. Evaporative coolers and radiant heaters maintained a relatively stable greenhouse temperature of about $20^{\circ} \mathrm{C}$ during the experiments. Soil moisture of pots was monitored every $2-3 \mathrm{~d}$ and maintained at $25 \%$ gravimetric soil water content with deionized water.

Dry aboveground biomass data were grouped by species and fit to multiple linear regression models described by Spitters (1983). The inverse of dry biomass per plant was predicted using the final densities per pot as independent variables. Models were

$$
\begin{aligned}
& y_{n}{ }^{-1}=\beta_{n} 0+\beta_{n n} N_{n}+\beta_{n c} N_{c} \text { (native species) } \\
& y_{c}{ }^{-1}=\beta_{c} 0+\beta_{c c} N_{c}+\beta_{c n} N_{n} \text { (crested wheatgrass), }
\end{aligned}
$$

where $y_{n}$ and $y_{c}$ represent the mean aboveground dry mass for native species and crested wheatgrass, respectively. The coefficients $N_{n}$ and $N_{c}$ represent the density per pot of the native species and crested wheatgrass, respectively, and the coefficients $\beta_{n} 0$ and $\beta_{c} 0$ represent the maximum aboveground dry mass for native species and crested wheatgrass grown in isolation, respectively. A lower value indicates higher biomass due to the inverse operation. The coefficients $\beta_{n n}$ and $\beta_{c c}$ quantify the intraspecific interference, and $\beta_{n c}$ and $\beta_{c n}$ quantify the interspecific interference for the native species and crested wheatgrass models, respectively. The ratios $\beta_{n n}: \beta_{n c}$ and $\beta_{c c}: \beta_{c n}$ determine the relative influence of each species on the variable response. For example, a $\beta_{c c}: \beta_{c n}$ ratio of 2 indicates that crested wheatgrass influences itself twice as much as the native species. In other words, it would take two plants of the native species to equal the influence of one crested wheatgrass plant on the response variable. The double ratio $\left(\beta_{n n}: \beta_{n c}\right):\left(\beta_{c c}: \beta_{c n}\right)$ was used to determine niche differentiation between species (Spitters 1983). Niche differentiation increases as the ratio departs from unity (1.0), meaning that native species and crested wheatgrass growth are decreasingly limited by the same resource.

The Spitters method of quantifying relative competitive ability using Equations 1 and 2 is inappropriate when one or more competition coefficients is negative, zero, or not a statistically significant component of the regression model. This is because 1) the association between a competition coefficient and its sign (+ or - ) is lost in the forming of ratios, 2) ratios are undefined if the denominator is zero, and 3) the value of the denominator is moot when the numerator is zero (Carpinelli 2005). To avoid misinterpretation of interference ratios and niche differentiation using the Spitters method, we converted values using the Absolute-Log method, then backtransformed values to a linear scale with an absolute-antilog function (Carpinelli 2005). Values often are identical and similarly interpreted. Absolute-antilog values are interpreted as follows: where intraspecific interference is greater than interspecific interference, interference ratios are greater than
0 ; where interspecific interference is greater than intraspecific interference, interference ratios are less than 0 ; and where there is complete niche overlap, niche differentiation equals 0 . Scatterplots of residuals vs. predicted values were used to determine the homogeneity of variances and the degree of model fit. Statistical significance of regression coefficients was determined at $\alpha=0.05$.

\section{RESULTS}

Germination of sagebrush and rabbitbrush was higher than predicted from preliminary germination percentage tests conducted on blotter paper. Actual densities ranged from 300 to 15000 seedlings $\cdot \mathrm{m}^{-2}$ for sagebrush and from 100 to 3000 seedlings $\cdot \mathrm{m}^{-2}$ for rabbitbrush. However, these densities still provided viable density matrices. The two trials were modeled separately because species aboveground dry biomass differed greatly between Trials 1 and 2 . In addition, applying the Absolute-Log method, then back-transforming coefficients revealed that interference and niche-differentiation ratios were in complete agreement between the Spitters and Absolute-Log methods, even though nonsignificant coefficients were found using the Spitters method.

Interference ratios indicated that interspecific effects were more important than intraspecific effects for predicting biomass of both native shrub species and bluebunch wheatgrass (Table 1). Ratios of intra- to interspecific interference in both trials varied from 0.09 to 0.37 for the shrubs and from 0.68 to 0.98 for bluebunch wheatgrass. By comparison, ratios of intrato interspecific interference for predicting biomass of squirreltail ranged from 1.01 in Trial 1 to 1.54 in Trial 2 . The inverse biomass of individual seedlings grown in isolation $\left(\beta_{n} 0\right)$ showed that rabbitbrush was nearly two-fold larger than sagebrush, both grasses were much larger than the shrubs, and squirreltail was about 1.4 times larger than bluebunch wheatgrass.

In stark contrast to native species, intraspecific interference was much more important than interspecific interference for predicting biomass of crested wheatgrass (Table 2). Intraspecific interference was between 17 and 43 times more important than interspecific interference when competing with shrubs. Similarly, intraspecific interference had over twice the influence on crested wheatgrass as interspecific interference from bluebunch wheatgrass. When grown with squirreltail, the ratio of intraspecific interference to interspecific interference ranged from 1.00 (Trial 1) to 0.86 (Trial 2). The inverse biomass of individual crested wheatgrass seedlings was rather constant across trials.

Niche differentiation $\left(\left[\beta_{n n}: \beta_{n c}\right]:\left[\beta_{c c}: \beta_{c n}\right]\right)$ between crested wheatgrass and either sagebrush or squirreltail was relatively stable across trials (Table 3). In contrast, niche differentiation between crested wheatgrass and rabbitbrush was higher, yet lower for bluebunch wheatgrass, when comparing Trials 1 and 2 , respectively. The highest and lowest niche differentiation between crested wheatgrass and a native species was by rabbitbrush (15.99) and squirreltail (1.01), respectively. With the exception of bluebunch wheatgrass in Trial 1, shrubs were more niche differentiated from crested wheatgrass than were the native grasses. 
Table 1. Multiple regression coefficients from the prediction equation $\left(y_{n}{ }^{-1}=\beta_{n} 0+\beta_{n n} N_{n}+\beta_{n c} N_{c}\right)^{1}$ for native species aboveground dry mass $\left(\mathrm{g} \cdot\right.$ plant $\left.^{-1}\right)$.

\begin{tabular}{|c|c|c|c|c|c|c|}
\hline Native species & $\begin{array}{c}\text { Individual } \\
\text { seedling } \beta_{n} 0\end{array}$ & $\begin{array}{c}\text { Intraspecific } \\
\text { interference } \beta_{n n}\end{array}$ & $\begin{array}{c}\text { Interspecific } \\
\text { interference } \beta_{n c}\end{array}$ & $\begin{array}{l}\text { Interference } \\
\text { ratio } \beta_{n n}: \beta_{n c}\end{array}$ & $R^{2}$ & $\begin{array}{l}\text { Absolute-antilog } \\
\text { interference ratio }\end{array}$ \\
\hline \multicolumn{7}{|l|}{ Trial 1} \\
\hline Sagebrush & $153.78(46.00)^{2}$ & $2.21 \times 10^{-2}(0.40)$ & $21.39 \times 10^{-2}(3.92)$ & 0.10 & 0.58 & -9.68 \\
\hline Rabbitbrush & $83.73(14.13)$ & $1.74 \times 10^{-2}(0.74)$ & $7.62 \times 10^{-2}(1.21)$ & 0.23 & 0.51 & -4.39 \\
\hline Bluebunch wheatgrass & $7.17(2.31)$ & $1.48 \times 10^{-2}(0.18)$ & $1.51 \times 10^{-2}(0.19)$ & 0.98 & 0.74 & -1.02 \\
\hline Squirreltail & $5.84(0.91)$ & $0.87 \times 10^{-2}(0.07)$ & $0.86 \times 10^{-2}(0.08)$ & 1.01 & 0.87 & 1.01 \\
\hline \multicolumn{7}{|l|}{ Trial 2} \\
\hline Sagebrush & $125.74(33.84)$ & $2.06 \times 10^{-2}(0.32)$ & $23.42 \times 10^{-2}(2.90)$ & 0.09 & 0.70 & -11.40 \\
\hline Rabbitbrush & $67.69(13.00)$ & $2.06 \times 10^{-2}(0.61)$ & $5.55 \times 10^{-2}(1.08)$ & 0.37 & 0.46 & -2.70 \\
\hline Bluebunch wheatgrass & $8.86(2.79)$ & $1.40 \times 10^{-2}(0.24)$ & $2.04 \times 10^{-2}(0.24)$ & 0.68 & 0.73 & -1.46 \\
\hline Squirreltail & $5.65(1.08)$ & $1.23 \times 10^{-2}(0.09)$ & $0.80 \times 10^{-2}(0.09)$ & 1.54 & 0.87 & 1.54 \\
\hline
\end{tabular}

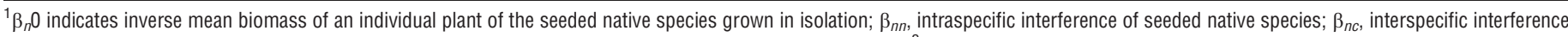
with crested wheatgrass; $\beta_{n n}: \beta_{n c}$, relative interference ratio of the native species and crested wheatgrass; $R^{2}$, coefficient of determination.

${ }^{2}$ Standard errors for coefficients significantly different from zero $(P<0.05)$.

\section{DISCUSSION}

Our study addresses both components of competitive ability for the native species we evaluated: the capacity to avoid being suppressed by crested wheatgrass (competitive response) and the ability to suppress crested wheatgrass (competitive effect; Keddy et al. 1998). As expected, interspecific interference from crested wheatgrass was not equivalent for the native species. Interspecific intereference was more influential on native species than intraspecific interference for all species except squirreltail. Furthermore, crested wheatgrass was more influenced by intraspecific interference except when grown with squirreltail. Species that are more influenced by intraspecific than interspecific interference typically have greater competitive effects (Aarssen 1983; Pyke and Archer 1991), especially when competing with species that share identical resource requirements (Spitters 1983; Sheley and Larson 1994). Native species not only varied for both components of competitive ability, but also differed considerably in niche differentiation. These results support our hypothesis that crested wheatgrass interference would not be equivalent for native species that vary in functional plant traits and growth form. In addition, these results provide insights into how native species can differentially perform when seeded 1) simultaneously with crested wheatgrass or 2) following manipulations to facilitate greater structural and functional diversity of crested wheatgrass-dominated plant communities.

The mechanisms responsible for variable competitive ability in the native grasses are not clear immediately because direct seedling interference between these native grasses and crested wheatgrass previously has not been evaluated. Furthermore, only generalizations about competitive abilities for soil resources, based on interactions with invasive annual grasses and native shrubs, exist for the two native grasses we evaluated (Eissenstat and Caldwell 1988; Arredondo et al. 1998; Monaco et al. 2003a; James 2008). Squirreltail and bluebunch wheatgrass do, however, differ in germination, emergence, and temporal growth patterns. These traits help clarify patterns of niche differentiation and interference competition (Carothers and Jaksic 1984). For example, certain squirreltail sources have more rapid germination than certain bluebunch wheatgrass sources across a range of temperatures and soil nitrogen levels

Table 2. Multiple regression coefficients from the prediction equation $\left(y_{c}^{-1}=\beta_{c} 0+\beta_{c c} N+\beta_{c n} N_{n}\right)^{1}$ of crested wheatgrass aboveground dry biomass $\left(\mathrm{g} \cdot\right.$ plant $\left.^{-1}\right)$.

\begin{tabular}{|c|c|c|c|c|c|c|}
\hline Native species & $\begin{array}{c}\text { Individual } \\
\text { seedling } \beta_{c} 0\end{array}$ & $\begin{array}{c}\text { Intraspecific } \\
\text { interference } \beta_{c c}\end{array}$ & $\begin{array}{c}\text { Interspecific } \\
\text { interference } \beta_{c n}\end{array}$ & $\begin{array}{l}\text { Interference } \\
\text { ratio } \beta_{c c}: \beta_{c n}\end{array}$ & $R^{2}$ & $\begin{array}{l}\text { Absolute-antilog } \\
\text { interference ratio }\end{array}$ \\
\hline \multicolumn{7}{|l|}{ Trial 1} \\
\hline Sagebrush & $6.29(1.95)^{2}$ & $0.99 \times 10^{-2}(0.16)$ & $4.19 \times 10^{-4}(1.66)$ & 23.62 & 0.49 & 23.62 \\
\hline Rabbitbrush & $2.84(0.85)$ & $1.12 \times 10^{-2}(0.07)$ & $6.32 \times 10^{-4}(\mathrm{NS})$ & 17.79 & 0.85 & 17.79 \\
\hline Bluebunch wheatgrass & $5.08(1.26)$ & $1.19 \times 10^{-2}(0.10)$ & $31.23 \times 10^{-4}(9.80)$ & 3.81 & 0.76 & 3.81 \\
\hline Squirreltail & $3.06(1.36)$ & $0.93 \times 10^{-2}(0.11)$ & $92.98 \times 10^{-4}(11.43)$ & 1.00 & 0.76 & 1.00 \\
\hline \multicolumn{7}{|l|}{ Trial 2} \\
\hline Sagebrush & $4.00(1.79)$ & $1.44 \times 10^{-2}(0.15)$ & $6.30 \times 10^{-4}(1.69)$ & 22.90 & 0.70 & 22.90 \\
\hline Rabbitbrush & $6.68(1.03)$ & $1.22 \times 10^{-2}(0.04)$ & $2.82 \times 10^{-4}$ (NS) & 43.23 & 0.82 & 43.23 \\
\hline Bluebunch wheatgrass & $6.15(1.52)$ & $1.21 \times 10^{-2}(0.13)$ & $54.66 \times 10^{-4}(12.45)$ & 2.20 & 0.72 & 2.20 \\
\hline Squirreltail & $5.46(1.61)$ & $1.01 \times 10^{-2}(0.13)$ & $116.28 \times 10^{-2}(13.11)$ & 0.86 & 0.77 & -1.16 \\
\hline
\end{tabular}

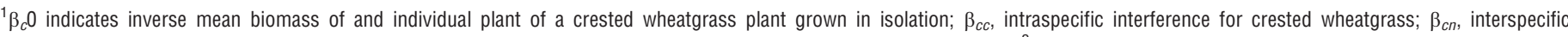
interference with the native species; $\beta_{c c}: \beta_{c n}$, relative interference ratio of crested wheatgrass and the native species; $R^{2}$, coefficient of determination.

${ }^{2}$ Standard errors for coefficients significantly different from zero $(P<0.05)$; NS $=$ not significant. 
Table 3. Double ratio $\left(\left[\beta_{n n}: \beta_{n c}\right]:\left[\beta_{c c}: \beta_{c n}\right]\right)$ assessing niche differentiation between crested wheatgrass and native species.

\begin{tabular}{lcc}
\hline \multicolumn{1}{c}{ Native species } & $\left(\beta_{n n}: \beta_{n c}\right):\left(\beta_{c n}: \beta_{c c}\right)$ & $\begin{array}{c}\text { Absolute-antilog } \\
\left(\beta_{n n}: \beta_{n c}\right):\left(\beta_{c n}: \beta_{c c}\right)\end{array}$ \\
\hline Trial 1 & & \\
$\quad$ Sagebrush & 2.44 & 2.44 \\
Rabbitbrush & 4.05 & 4.05 \\
$\quad$ Bluebunch wheatgrass & 3.73 & 3.73 \\
Squirreltail & 1.01 & 1.01 \\
Trial 2 & & \\
Sagebrush & 2.01 & 2.01 \\
Rabbitbrush & 15.99 & 15.99 \\
$\quad$ Bluebunch wheatgrass & 1.51 & 1.51 \\
Squirreltail & 1.33 & 1.33 \\
\hline
\end{tabular}

(Monaco et al. 2003b; Young et al. 2003). Rapid germination and emergence are particularly important because crested wheatgrass cultivars have been intensively selected for this trait under low temperature and variable soil depths (Asay et al. 2003). Consequently, rapid emergence might have helped growth of squirreltail precede that of bluebunch wheatgrass, resulting in squirreltail having less niche differentiation and interfering relatively more with crested wheatgrass under controlled greenhouse conditions.

The variation for interference and niche differentiation between the native shrubs and grasses might be inherently associated with key life history differences in rooting patterns and resource use between grass and shrub growth forms. As seedlings, the grasses were much more productive than the shrubs in our study. In addition, compared to shrubs, fastergrowing grass species typically produce finer roots (Ryser and Lambers 1995; Peek et al. 2005) with greater specific root length and nutrient uptake capacity (Jackson and Caldwell 1989; Bilbrough and Caldwell 1997; Leonard et al. 2008). These growth form differences corroborate our observation that the intraspecific:interspecific interference ratio for crested wheatgrass growth was nearly an order of magnitude greater for the native shrubs relative to the native grasses we evaluated. Native shrubs provided little interspecific interference on crested wheatgrass seedlings, and the interference ratio for native grasses was much closer to 1.0 , which implies that the growth of native shrubs might be more negatively impacted by crested wheatgrass when seeded simultaneously. Alternatively, both native grasses might be capable of rivaling interference from crested wheatgrass when seedlings dynamically emerge and interact in rangeland settings.

Although native shrubs provided little interspecific interference, these shrubs are capable of establishing and persisting in recently planted crested wheatgrass seedings where seed banks of native shrubs still exist (Frischknecht and Bleak 1957; Johnson and Payne 1968). In addition, the variation in big sagebrush and rabbitbrush recruitment within crested wheatgrass seedings has been studied for nearly half a century in the Intermountain West (Frischknecht 1963; Hull and Klomp 1966). These studies provide insights into how seedlings of sagebrush and rabbitbrush variably interact with crested wheatgrass. The general consensus is that Wyoming big sagebrush is more similar to crested wheatgrass than rubber rabbitbrush for life-history traits, root distribution, and resource acquisition patterns. For example, rabbitbrush has fewer lateral roots, and root growth is less dependent on precipitation pulses than in sagebrush and crested wheatgrass (Frischknecht 1963; Gebauer et al. 2002; Leffler et al. 2004). Furthermore, growth and establishment of sagebrush tend to be more similar to crested wheatgrass than to rabbitbrush, because leaf production and vegetative growth of sagebrush ensue nearly $25 \mathrm{~d}$ earlier than rabbitbrush (Bilbrough and Caldwell 1997). Sagebrush roots also maintain soil nitrogen $(\mathrm{N})$ uptake under heavy drought stress (Matzner and Richards 1996) and have higher soil $\mathrm{N}$ acquisition and specific root length than roots of rabbitbrush (Duke and Caldwell 2001). These functional differences collectively help explain crested wheatgrass's greater negative effect on mean biomass of sagebrush, as well as intraspecific/interspecific interference ratios being consistently higher for rabbitbrush than sagebrush. Because intraspecific density had similar effects on both native shrubs, our results indicate that crested wheatgrass density differentially interferes with growth of sagebrush and rabbitbrush. Key differences in life-history traits and resource use also explain our observations of rabbitbrush having nonsignificant effects on crested wheatgrass biomass production and niche differentiation being greatest between rabbitbrush and crested wheatgrass.

\section{MANAGEMENT IMPLICATIONS}

Because the seed densities we evaluated were comparable to rates used when seeding native species within rehabilitated crested wheatgrass-dominated communities (Fansler 2007; Hulet et al. 2008), our research has important implications for both diversification of crested wheatgrass-dominated communities and mixed seedings of crested wheatgrass and native species (Cox and Anderson 2004; Waldron et al. 2005). If persistent seed banks of crested wheatgrass or weeds are not adequately reduced prior to seeding, native species establishment and persistence can be seriously compromised (Wilson and Partel 2003; Henderson and Naeth 2005; Fansler 2007; Hulet et al. 2008). However, because native species' competitive responses and effects were not equivalent, their establishment can be variably influenced by managerial treatments to reduce crested wheatgrass dominance (Pellant and Lysne 2005). Greater crested wheatgrass interference on native shrubs relative to the grasses suggests that reducing crested wheatgrass seed banks and young emerging seedlings can be especially important for successfully establishing the shrubs we evaluated. Alternatively, establishment of these native grasses is expected to be higher than the shrubs even when management treatments to reduce crested wheatgrass seed banks are ineffective. Although the ability of native species and crested wheatgrass to establish in synchrony following a mixed seeding is relatively understudied (but see Waldron et al. 2005; Thompson et al. 2006), our results suggest that species with rapid germination and seedling growth are more likely to establish with crested wheatgrass because they experience less interference at this developmental stage. Although shrub growth suffers greater interference from crested wheatgrass, seedlings that do establish can persist because of high niche differentiation. 
Further research to define density-dependent interference and niche differentiation between native species and crested wheatgrass under contrasting management strategies is needed to scale up the seedling interaction predictions we posit. Because our study only investigated the first $45 \mathrm{~d}$ of seedling growth, determining the longer-term impacts of variable seedling densities on the interactions betweens native species and crested wheatgrass is needed.

\section{ACKNOWLEDGMENTS}

Justin Williams and Sara Law assisted with data collection and plant rearing. We also thank Drs Michael Carpinelli and Thomas Jones for their generous time and editorial insights.

\section{LITERATURE CITED}

Aarssen, L. W. 1983. Ecological combining ability and competitive combining ability in plants: toward a general evolutionary theory of coexistence in systems of competition. American Naturalist 122:707-731.

Aguirre, L., and D. A. Johnson. 1991. Influence of temperature and cheatgrass competition on seedling development of two bunchgrasses. Journal of Range Management 44:347-354.

Arredondo, J. T., T. A. Jones, and D. A. Johnson. 1998. Seedling growth of Intermountain perennial and weedy annual grasses. Journal of Range Management 51:584-589.

Asay, K. H., N. J. Chatterton, K. B. Jensen, T. A. Jones, B. L. Waldron, and W. H. HoRTon. 2003. Breeding improved grasses for semiarid rangelands. Arid Land Research and Management 17:469-478.

BIlbrough, C. J., And M. M. Caldwell. 1997. Exploitation of springtime ephemeral N pulses by six Great Basin plant species. Ecology 78:231-243.

Biodinı, M. E., C. D. Bonham, and E. F. Redente. 1985. Secondary successional patterns in a sagebrush (Artemisia tridentata) community as they relate to soil disturbance and soil biological activity. Vegetatio 60:25-36.

Bock, C. E., J. H. Bock, L. Kennedy, and Z. F. Jones. 2007. Spread of non-native grasses into grazed versus ungrazed desert grasslands. Journal of Arid Environments 71:229-235.

Carothers, J. H., and F. M. Jaksic. 1984. Time as a niche difference: the role of interference competition. Oikos 43:403-406.

Carpinelli, M. F. 2005. The Absolute-Log method of quantifying relative competitive ability and niche differentiation. Weed Technology 19:972978.

Chambers, J. C., And J. A. MacMahon. 1994. A day in the life of a seed: movements and fates of seeds and their implications for natural managed systems. Annual Review of Ecology and Systematics 25:263-292.

Chesson, P. 2000. Mechanisms of maintenance of species diversity. Annual Review of Ecology, Evolution, and Systematics 31:343-366.

Cox, R. D., AND V. J. Anderson. 2004. Increasing native diversity of cheatgrassdominated rangeland through assisted succession. Journal of Range Management 57:203-210.

Duke, S. E., and M. M. Caldwell. 2001. Nitrogen acquisition from different spatial distributions by six Great Basin species. Western North American Naturalist 61:93-102.

Eissenstat, D. M., and M. M. Caldwell. 1987. Characteristics of successful competitors: an evaluation of potential growth rate in two cold desert tussock grasses. Oecologia 71:167-173.

Eissenstat, D. M., and M. M. Caldwell. 1988. Competitive ability is linked to rates of water extraction: a field study of two aridland tussock grasses. Oecologia $75: 1-7$.

Evans, R. A., and J. A. Young. 1978. Effectiveness of rehabilitation practices following wildfire in a degraded big sagebrush-downy brome community. Journal of Range Management 31:185-188.
FansLer, V. A. 2007. Establishing native plants in crested wheatgrass stands using successional management [thesis]. Corvallis, OR, USA: Oregon State University. $108 \mathrm{p}$.

Francis, M. G., and D. A. PYKe. 1996. Crested wheatgrass-cheatgrass seedling competition in a mixed-density design. Journal of Range Management 49:432-438

FrisCHKNECHT, N. C. 1963. Contrasting effects of big sagebrush and rubber rabbitbrush on production of crested wheatgrass. Journal of Range Management 16:70-74.

FrischKNeCht, N. C., AND A. T. BLEAK. 1957. Encroachment of big sagebrush on seeded range in northeastern Nevada. Journal of Range Management 10:165-170.

Gebauer, R. L., S. Schwinning, and J. R. Ehleringer. 2002. Interspecific competition and resource pulse utilization in a cold desert community. Ecology 83:2602-2616.

Gibson, D. J., J. Connolly, D. C. Hartnett, and J. D. Weidenhamer. 1999. Designs for greenhouse studies of interactions between plants. Journal of Ecology 87:1-16.

Henderson, D. C., and M. A. Naeth. 2005. Multi-scale impacts of crested wheatgrass invasion in mixed-grass prairie. Biological Invasions 7:639-650.

Horn, H. S. 1974. The ecology of secondary succession. Annual Review of Ecology, Evolution, and Systematics 5:25-37.

Hulet, A., B. Roundy, J. Coleman, and B. Jessop. 2008. Diversification of crested wheatgrass stands in Utah. Abstracts of the 2008 Joint Meeting of the Society for Range Management and the America Forage and Grassland Council. Available at: http://srm.confex.com/srm/2008/techprogram/P2024.HTM. Accessed 15 May 2009.

HuLL, A. C., JR., AND G. J. KLomp. 1966. Longevity of crested wheatgrass in the sagebrush-grass type in southern Idaho. Journal of Range Management 19:5-11.

Jackson, R. B., and M. M. Caldwell. 1989. The timing and degree of root proliferation in fertile-soil microsites for three cold-desert perennials. Oecologia 81:149-153.

JAMES, J. J. 2008. Leaf nitrogen productivity as a mechanism driving the success of invasive annual grasses under low and high nitrogen supply. Journal of Arid Environments 72:1775-1784.

James, J. J., K. W. Davies, R. L. Sheley, and Z. T. Aanderud. 2008. Linking nitrogen partitioning and species abundance to invasion resistance in the Great Basin. Oecologia 156:637-648.

Johnson, J. R., and G. F. Payne. 1968. Sagebrush reinvasion as affected by some environmental factors. Journal of Range Management 21:209-213.

Keddy, P., L. H. Fraser, AND I. C. Wisheu. 1998. A comparative approach to examine competitive response of 48 wetland plant species. Journal of Vegetation Science 9:777-786.

KLEIJN, D. 2003. Can establishment characteristics explain the poor colonization success of late successional grassland species on ex-arable land? Restoration Ecology 11:131-138.

Leffler, A. J., C. Y. Ivans, R. J. Ryel, and M. M. Caldwell. 2004. Gas exchange and growth responses of the desert shrubs Artemisia tridentata and Chrysothamnus nauseosus to shallow- vs. deep-soil water in a glasshouse experiment. Environmental and Experimental Botany 51:9-19.

Leonard, E. D., T. A. Monaco, J. M. Stark, and R. J. Ryel. 2008. Invasive forb, annual grass, and exotic shrub competition with three sagebrush-steppe growth forms: acquisition of a spring ${ }^{15} \mathrm{~N}$ tracer. Invasive Plant Science and Management 1:168-177.

Marlette, G. M., and J. E. Anderson. 1986. Seed banks and propagule dispersal in crested-wheatgrass stands. Journal of Applied Ecology 23:161-175.

Matzner, S. L., And J. H. Richards. 1996. Sagebrush (Artemisia tridentata Nutt.) roots maintain nutrient uptake capacity under water stress. Journal of Experimental Botany 47:1045-1056.

Meyer, S. E., E. D. McArthur, and G. L. Jorgensen. 1989. Variation in germination response to temperature in rubber rabbitbrush (Chrysothamnus nauseosus: Asteraceae) and its ecological implications. American Journal of Botany 76:981-991.

Monaco, T. A., D. A. Johnson, J. M. Norton, T. A. Jones, K. J. Connors, J. B. Norton, and M. B. Redinbaugh. 2003a. Contrasting responses of Intermountain West grasses to soil nitrogen. Journal of Range Management 56:282-290. 
Monaco, T. A., C. T. MacKown, D. A. Johnson, T. A. Jones, J. M. Norton, J. B. Norton, and M. G. Redinbaugh. 2003b. Nitrogen effects on seed germination and seedling growth. Journal of Range Management 56:646-653.

Morales-Romero, D., and F. Molina-Freaner. 2008. Influence of buffelgrass pasture conversion on the regeneration and reproduction of the columnar cactus, Pachycereus pecten-aboriginum, in northwestern Mexico. Journal of Arid Environments 72:228-237.

Mueggler, W. F., and J. P. Blaisdell. 1958. Effects on associated species of burning, rotobeating, spraying, and railing sagebrush. Journal of Range Management 11:61-66.

Peek, M. S., A. J. Leffler, C. Y. Ivans, R. J. Ryel, and M. M. Caldwell. 2005. Fine root distribution and persistence under field conditions of three co-occurring Great Basin species of different life form. New Phytologist 165:171-180.

Pellant, M., and C. R. Lysne. 2005. Strategies to enhance plant structure and diversity in crested wheatgrass seedings. In: N. L. Shaw, M. Pellant, and S. B. Monsen [comps.]. Sage-grouse Habitat Restoration Symposium Proceedings; 4-7 June 2001; Boise, ID, USA. Fort Collins, CO, USA: US Department of Agriculture, Forest Service, Rocky Mountain Research Station, RMRS-P-38. p. 81-92.

PYKE, D. A. 1990. Comparative demography of co-occurring introduced and native tussock grasses: persistence and potential expansion. Oecologia 82:537-543.

Pyke, D. A., And S. Archer. 1991. Plant-plant interactions affecting plant establishment and persistence on revegetated rangeland. Journal of Range Management 44:550-557.

Pywell, R. F., J. M. Bullock, D. B. Roy, L. Warman, K. J. Walker, and P. Rotherby. 2003. Plant traits as predictors of performance in ecological restoration. Journal of Applied Ecology 40:65-77.

RADOSEVICH, S. R. 1987. Methods to study interactions among crops and weeds. Weed Technology 1:190-198.

Redente, E. F., J. E. Friedlander, and T. Mclendon. 1992. Response of early and late semiarid seral species to nitrogen and phosphorus gradients. Plant and Soil 140:127-135.
Ryser, P., and H. Lambers. 1995. Root and leaf attributes accounting for the performance of fast- and slow-growing grasses at different nutrient supply. Plant and Soil 170:251-265.

Schmidt, C. D., K. R. Hickman, R. Channell, W. J. Stark, and K. R. Harmoney. 2008. Competitive ability of native grasses and non-native (Old World bluestems; Bothriochloa spp.) grasses. Plant Ecology 197:69-80.

Sharp, L. A., K. SAndeRS, And N. Rimbey. 1992. Variability of crested wheatgrass production over 35 years. Rangelands 14:153-168.

Sheley, R. L., and L. L. LaRson. 1994. Comparative growth and interference between cheatgrass and yellow starthistle seedlings. Journal of Range Management 47:470-474.

SPITTERS, C. J. T. 1983. An alternative approach to the analysis of mixed cropping experiments. I. Estimation of competition effects. Netherlands Journal of Agricultural Science 31:1-11.

Thompson, T. W., B. A. Roundy, E. D. McArthur, B. D. Jessop, B. Waldron, and J. N. Davis. 2006. Fire rehabilitation using native and introduced species: a landscape trial. Rangeland Ecology and Management 59:237-248.

Tueller, P. T., and K. A. Platou. 1991. A plant succession gradient in a big sagebrush grass ecosystem. Vegetatio 94:57-68.

Waldron, B. L., T. A. Monaco, K. B. Jensen, R. D. Harrison, A. J. Palazzo, and J. D. KulBetr. 2005. Coexistence of native and introduced perennial grasses following simultaneous seeding. Agronomy Journal 97:990-996.

Wilson, S. D., And M. Partel. 2003. Extirpation or coexistence? Management of a persistent introduced grass in a prairie restoration. Restoration Ecology 11:410-416.

Wright, H. A., and J. O. Klemmedson. 1965. Effects of fire on bunchgrass of the sagebrush-grass region in southern Idaho. Ecology 46:680-688.

Young, J. A., C. D. Clements, and T. Jones. 2003. Germination of seeds of big and bottlebrush squirreltail. Journal of Range Management 56:277-281.

Young, R. P., And R. F. Millek. 1985. Response of Sitanion hystrix (Nutt.) J. G. to prescribed fire. American Midland Naturalist 113:182-187. 